\title{
ANALISIS PRODUK UNGGULAN AGROINDUSTRI PERIKANAN LAUT DI KABUPATEN REMBANG
}

\author{
Giyatmi"), Agus Heri Purnomo") dan Musa Hubeis"*)
}

\begin{abstract}
ABSTRAK
Kajian telah dilakukan untuk menganalisis produk agroindustri perikanan laut yang dapat diunggulkan di Kabupaten Rembang. Kajian dimulai dengan mengidentifikasi potensi perikanan laut, pemilihan komoditas potensial dan produk unggulan agroindustri, selanjutnya dilakukan analisis kelayakan usaha dari produk unggulan tersebut. Proses pemilihan komoditas potensial dan pemilihan produk unggulan menggunakan teknik Proses Hierarki Analitik/PHA, sedangkan kelayakan finansial usaha dianalisis berdasarkan kriteria nilai B/Cratio, NPV, IRR dan PBP. Berdasarkan kriteria-kriteria yang disusun untuk pemilihan komoditas bagi produk unggulan agroindustri diketahui bahwa ketersediaan bahan baku dan nilai ekonomis bahan baku merupakan faktor yang determinatif dalam penilaian alternatif komoditas potensial. Untuk menentukan produk unggulan agroindustri, terlihat bahwa nilai tambah produk, ketersediaan dan kontinuitas bahan baku; serta peluang pasar merupakan faktor yang determinatif. Dari hasil pembobotan dan skoring terhadap beberapa jenis komoditas dan teknologi pasca panen yang digunakan diketahui bahwa produk agroindustri perikanan laut yang dapat diunggulkan di Kabupaten Rembang adalah ikan teri kering-asin dan pindang ikan layang. Analisis finansial menunjukkan kedua produk unggulan tersebut layak untuk diusahakan. Hasil analisis sensitivitas memberikan petunjuk bahwa apabila terjadi penurunan produksi sebesar $50 \%$ dan peningkatan harga ikan sampai dengan $11 \%$ untuk ikan teri dan $8 \%$ untuk ikan layang, yang umumnya terjadi pada masa paceklik, maka harus dilakukan penyesuaian dengan cara meningkatkan harga jual produk minimal sebesar $2 \%$ untuk ikan teri kering-asin dan 3\% untuk pindang ikan layang.
\end{abstract}

\section{ABSTRACT: Analysis of specialty products for the marine-fisheries agroindustry in} Rembang district. By: Giyatmi, Agus Heri Purnomo and Musa Hubeis

An analysis has been conducted on various marine fisheries products in Rembang District to determine those that can be developed as the district's agroindustry product specialty. The analytical process starts with identification of marine fisheries potential, followed by selection of potential commodities, determination of agroindustry specialty products, and feasibility study on the development of those products. The processes of selecting potential commodities and determining agroindustry specialty products follow the Analytical Hierarchy Process (AHP) approach while the feasibility analysis is based on three economic indicators, namely B/C ratio, NPV dan IRR. Based on all criteria normally relevant to the selection of agroindustry specialty products, it is found that the availability and economic value of raw materials are the crucial factors in the valuation of potential alternative commoditiy. Meanwhile, availability and continuity of raw materials, and market opportunity are the major components in the determination of agroindustry specialty products. Weighting and scoring which were carried out on various commodities and processing technologies resulted in a conclusion that the most prospective marine fisheries products that can be developed as specialty products for Rembang District were salted-dried anchovy and boiled-salted scads. Financial analysis on the two products shows that in order to maintain feasibility, adjustments in terms of increases in selling price are necessary in cases where production should decrease and/or the main input price (raw material) should increase.

KEYWORDS: $\quad$ specialty products, marine fisheries, Rembang, AHP

\section{PENDAHULUAN}

Produksi perikanan laut Kabupaten Rembang dari tahun ke tahun menunjukkan adanya peningkatan baik dari sisi volume maupun nilainya. Pada tahun 1996, volume produksi $31.992,9$ ton dengan nilai $\mathrm{Rp}$. 49.593.877.000,- (BPS Prop. Jateng, 1997) dan pada tahun 2000 , volumenya meningkat menjadi 50.783,3 ton dengan nilai Rp. 286.703.982.000,- (BPS Prop. Jateng, 2002), yang berarti selama kurun waktu 5

Dosen Jurusan Teknologi Pangan, Fakultas Pertanian Universitas Sahid

Peneliti pada Pusat Riset Pengolahan Produk dan Sosial Ekonomi Kelautan dan Perikanan

-) Guru besar IImu Manajemen Industri, Institut Pertanian Bogor 
tahun meningkat sebesar $58,7 \%$ dari sisi volume produksi dan $478 \%$ dari sisi nilai produksi. Dari data perikanan tahun 2000 (BPS Prop. Jateng, 2002) dapat diketahui bahwa berdasarkan volume produksinya Kabupaten Rembang merupakan penghasil perikanan laut terbesar kedua setelah Kota Pekalongan, tetapi dari sisi nilai produksi menempati urutan pertama, dimana sumbangan terhadap nilai produksi di Propinsi Jawa Tengah mencapai $26,7 \%$.

Diketahui tingkat konsumsi ikan nasional pada tahun 2001 sebesar 21,78 kg per kapita. Jumlah penduduk di Kabupaten Rembang pada tahun 2001 adalah 559.523 orang; apabila diasumsikan bahwa hasil perikanan yang dikonsumsi tersebut adalah ikan segar, maka kebutuhan konsumsi lokal adalah sebesar 12.186,4 ton. Dengan demikian, sejumlah besar bahan baku komoditas perikanan tidak terserap di tingkat lokal.

Kelebihan produksi hasil perikanan Kabupaten Rembang, selama ini diketahui sebagian dikirim dalam bentuk segar keluar daerah di sekitar Rembang seperti Demak, Pati, Blora, Kudus dan Jepara atau ke wilayah lain seperti Surabaya, Solo, Semarang dan Jakarta. Berdasarkan hasil wawancara yang dilakukan selama penelitian, diperoleh informasi bahwa pengiriman dalam bentuk segar mencapai $40-60 \%$. Sebagian jumlah lain diolah menjadi berbagai bentuk ikan olahan tradisional seperti pindang, kering-asin, dan pemanggangan.

Kegiatan penanganan pasca panen bagi pengolahan hasil perikanan laut yang dilaksanakan oleh masyarakat nelayan pada umumnya merupakan jenis usaha perikanan rakyat dan berskala rumah tangga dengan teknologi tradisional, seperti penggaraman, perebusan, pengeringan, pengasapan dan fermentasi. Jenis usaha ini seringkali memberikan nilai tambah yang relatif rendah. Kebanyakan para pengambil kebijakan atau pelaku usaha menginginkan jenis produk yang dapat memberikan nilai tambah yang lebih besar yang selanjutnya dapat dijadikan produk unggulan bagi masing-masing daerah. Namun demikian, kurangnya informasi mengenai potensi sumber daya dan teknologi pasca panen bagi masingmasing komoditas menyulitkan berbagai daerah menentukan jenis produk yang akan dijadikan sebagai unggulan.

Tujuan penelitian ini adalah untuk menentukan produk agroindustri perikanan laut yang dapat dikembangkan di Kabupaten Rembang sebagai produk unggulan, khususnya didasarkan pada sumber daya lokal yang dimilikinya. Produk unggulan agroindustri terpilih tersebut dianalisis kelayakan usahanya dan dilakukan uji sensitivitas terhadap usaha tersebut.

\section{METODE}

\section{Tahapan Penelitian}

Analisis produk unggulan agroindustri perikanan laut di Kabupaten Rembang dimulai dengan (1) mengidentifikasi potensi perikanan laut, (2) menentukan komoditas potensial dan (3) menentukan produk unggulan agroindustri, dan (4) menganalisis kelayakan usaha produk unggulan terpilin. Agrondustri perikanan laut yang dimaksudkan pada penelitian ini adalah usaha pengolahan/penanganan berbahan baku hasil perikanan tangkap di laut dari nelayan.

Identifikasi potensi perikanan laut diantaranya adalah untuk mengetahui volume dan kontinuitas produksi hasil perikanan laut di Rembang selama lima tahun terakhir. Selain itu juga diidentifikasi jenis-jenis penanganan atau pengolahan yang dilakukan oleh pelaku usaha terhadap hasil perikanan laut. Penentuan komoditas potensial dilakukan untuk menyeleksi ragam komoditas perikanan laut yang dihasilkan di Kabupaten Rembang, selanjutnya digunakan untuk menentukan produk unggulan agroindustri yang dapat dikembangkan di daerah tersebut. Tahapan terakhir penelitian ini adalah mengukur tingkat kelayakan agroindustri produk terpilih dilihat dari aspek finansialnya.

\section{Teknik Pengumpulan Data}

Pada penelitian ini data diperoleh melalui studi pustaka dan survei lapang untuk mendapatkan data primer dan sekunder. Data primer diperoleh melalui survei lapang, wawancara mendalam (in-depth interview) dan pengisian kuesioner. Data sekunder diperoleh dari beberapa literatur dan laporan tahunan dari instansi terkait.

Pengisian kuesioner melibatkan responden yang dipilih dengan menggunakan metode purposive sampling. Dengan teknik pengambilan responden melalui metode tersebut, responden merupakan pakar yang dipilih secara sengaja dan cermat sehingga relevan dengan rancangan penelitian yang akan dilaksanakan. Dalam penelitian ini pakar yang dipilih adalah Kepala Dinas Perikanan dan Kelautan Kabupaten Rembang serta dua orang pelaku agroindustri di Kabupaten Rembang

\section{Teknik Analisis Data}

Proses pemilihan komoditas potensial dan pemilihan produk unggulan menggunakan beberapa kriteria yang diperkirakan merupakan faktor penentu. Kriteria-kriteria pemilihan tersebut dibobotkan dengan teknik Proses Hierarki Analitik/PHA melalui metode 
komparasi berpasangan (full pairwise method) dengan skala komparasi antara 1 sampai 9 atau kebalikannya. Pembobotan kriteria pemilihan dilakukan dengan mengambil pendapat dari pakar yang berasal dari Dinas Perikanan dan Kelautan dan pelaku usaha agroindustri perikanan laut di Kabupaten Rembang. Selanjutnya, dilakukan pemilihan alternatif komoditas atau produk dengan teknik PHA melalui metode langsung (direct method) dengan nilai 1 sampai 10

Proses Hierarki Analitik merupakan alat analisis yang dikembangkan oleh Saaty (1980) yang mampu memberikan dukungan untuk pengambilan keputusan yang punya banyak kriteria, dikarenakan kemampuannya melacak konsistensi logis pertimbangan-pertimbangan yang digunakan dan menyediakan suatu skala yang mampu mengukur hal-hal yang intangible. Prinsip pokok metode PHA didasarkan pada tiga prinsip, yaitu penyusunan hierarki, penentuan prioritas dan pengukuran konsistensi logis

Penyusunan hierarki adalah langkah pendefinisian masalah yang rumit dan kompleks sehingga menjadi lebih jelas dan detil. Hierarki keputusan disusun berdasarkan pandangan pihak-pihak yang memiliki keahlian dan pengetahuan dibidang bersangkutan. Keputusan yang akan diambil sebagai tujuan dijabarkan menjadi elemen-elemen yang lebih rinci hingga mencapai suatu tahapan yang terukur. Hierarki permasalahan akan mempermudah pengambil keputusan untuk menganalisis dan menarik kesimpulan terhadap permasalahan tersebut.

Prioritas elemen-elemen kriteria merupakan bobot kontribusi kriteria terhadap tujuan atau menentukan peringkat elemen-elemen menurut relatif pentingnya. Prioritas ini berdasarkan pandangan para pakar dan pihak-pihak yang berkepentingan terhadap pengambilan keputusan, baik secara langsung maupun tidak langsung. Elemen pada tingkat yang tinggi berfungsi sebagai kriteria. Hasil dari proses pembedaan adalah suatu vektor prioritas. Pada penelitian ini, penentuan prioritas dilakukan dengan metode perbandingan berpasangan antar dua elemen kriteria untuk menentukan bobot masing-masing kriteria dan metode langsung untuk menentukan urutan alternatif komoditas atau produk pilihan.

Pengukuran konsistensi logis digunakan untuk mengukur tingkatan konsistensi jawaban para pakar dalam menentukan prioritas elemen yang akan menentukan validitas data dan hasil pengambilan keputusan. Konsistensi mempunyai dua pengertian, yang pertama, pemikiran atau obyek yang serupa telah dikelompokkan menurut homogenitas dan relevansinya. Sedangkan yang kedua adalah bahwa intensitas relasi antar gagasan atau obyek yang didasarkan pada suatu kriteria tertentu. Secara umum, responden harus memiliki konsistensi dalam melakukan perbandingan elemen. Jika $A>B$ dan $B>$ C maka secara logis $A>C$. Pada penelitian ini, pengolahan data yang diperoleh melalui pengisian kuesioner menggunakan software Criterium Decision Plus Version 2.0.2/s - 1997

Pemilihan kesesuaian teknologi pasca panen bagi komoditas perikanan laut didasarkan pada bentukbentuk alternatif pengolahan/penanganan bagi usaha agroindustri yang mengikuti definisi Austin (1992) dan Brown (1994), yang menyatakan bahwa agroindustri adalah industri yang mengolah bahan baku hasil pertanian yang berupa tanaman atau hewan, yang meliputi transformasi dan pengawetan yang melalui perubahan fisik atau kimiawi, penyimpanan, pengemasan dan distribusi. Berdasarkan definisi tersebut maka bentuk teknologi pasca panen bagi usaha agroindustri yang telah dan/atau mungkin digunakan sebagai alternatif adalah penanganan hidup, segar dan pembekuan, pengolahan dengan pemindangan, pengasinan/pengeringan, pengasapan/ pemanggangan, fermentasi/terasi dan pengalengan, serta pembuatan surimi dan tepung ikan

Untuk menganalisis kelayakan usaha untuk produk unggulan agroindustri perikanan laut dilakukan melalui perhitungan kelayakan finansial dengan kriteria-kriteria kelayakan seperti : NPV, IRR, Net B/C, dan PBP (Kadariah et al., 1978). Uji sensitivitas juga dilaksanakan untuk mengetahui kelayakan usaha apabila terjadi perubahan pada beberapa parameter seperti adanya penurunan volume bahan baku kenaikan harga bahan baku atau kenaikan harga jual produk.

\section{HASIL DAN BAHASAN}

\section{Produksi Perikanan Laut di Kabupaten Rembang}

Besarnya jumlah produksi perikanan laut dari suatu daerah memperlihatkan ketersediaan bahan baku agroindustri untuk daerah tersebut juga besar Volume dan nilai produksi perikanan laut di Kabupaten Rembang selama periode 1996-2000 menunjukkan perkembangan, yaitu $31.992,6$ ton dengan nilai $R p$ 49.593.877,- pada tahun 1996; $36.318,6$ ton dengan nilai Rp. 32.920.675,- pada tahun 1997; 54.608,6 ton dengan nilai Rp. 98.599.735,- pada tahun 1998; 44.349, 7 ton dengan nilai Rp. 184.622.855,- pada tahun 1999; dan 50.783,3 ton dengan nilai Rp. 286.703.982,pada tahun 2000 (BPS, 1997 - 2002). Produksi perikanan laut di Kabupaten Rembang dihasilkan dari penangkapan ikan oleh nelayan lokal maupun dari luar 
daerah Rembang (Pati, Pekalongan dan Jawa Timur). Usaha penangkapan ikan di Kabupaten Rembang diarahkan pada jenis ikan yang mempunyai nilai ekonomis penting, antara lain jenis tongkol, kakap, tengiri, bawal, cumi-cumi dan rajungan.

Teknologi pasca panen yang banyak digunakan oleh pelaku agroindustri di Kabupaten Rembang adalah pengesan ikan untuk menjaga kesegaran ikan selama pemasaran, pengolahan menjadi pindang, pengeringan/pengasinan dan pemanggangan/ pengasapan. Pemilihan teknologi pasca panen para pelaku agroindustri perikanan laut didasarkan pada pertimbangan awal, yaitu untuk ikan yang memiliki nilai ekonomis tinggi dan kualitas ikan saat pendaratan masih baik akan diperlakukan dengan pengesan. Untuk beberapa jenis ikan seperti layang, selar dan kembung, apabila ikan yang diperoleh agak kurang baik, akan dilakukan proses pemindangan. Ikan yang kurang baik, kecuali untuk jenis teri nasi, pada umumnya diperlakukan dengan pengeringan/ pengasinan

\section{Pemilihan Komoditas Potensial dan Kesesuaian Teknologi Pasca Panen}

\section{Pemilihan komoditas potensial}

Salah satu kendala yang dihadapi industri perikanan, baik industri yang berteknologi maju maupun industri pengolahan tradisional adalah kesulitan memperoleh bahan baku, karena kedua jenis industri tersebut mengandalkan bahan baku hasil tangkapan perikanan rakyat (Poernomo et al., 2001). Ketersediaan bahan mentah merupakan persyaratan mutlak yang diperlukan untuk menjamin keberlanjutan suatu kegiatan industri pengolahan, termasuk industri perikanan. Bahan mentah tersebut harus memenuhi syarat, baik secara kuantitas maupun kualitas Bahkan bagi industri yang mengolah limbah perikanan, kualitas bahan baku yang tinggi merupakan prasyarat yang tidak dapat ditawar lagi (Poernomo et al., 2001). Banyak perusahaan yang tidak dapat beroperasi pada kapasitas produksi dan bahkan banyak diantaranya berhenti beroperasi, sebagai akibat tidak tesedianya bahan mentah yang memadai (Irianto et al., 2001).

Berdasarkan data dari Dinas Perikanan dan Kelautan Jawa Tengah dan hasil pendapat pakar, dipilih 15 (lima belas) alternatif komoditas perikanan laut yang mempunyai potensi untuk dikembangkan menjadi bahan baku agroindustri, yaitu Layang, Selar, teri, tembang, kembung, tengiri, tongkol, peperek, merah, ekor kuning, tigawaja, pari, rebon, cumi-cumi dan Rajungan. Hasil pembobotan masing-masing kriteria dan urutan prioritas alternatif komoditas potensial berdasarkan penilaian pakar dari Dinas Perikanan dan Kelautan dan pelaku usaha agroindustri di Kabupaten Rembang disajikan pada Tabel 1 dan Tabel 2.

Tabel 1. Urutan prioritas kriteria pemilihan komoditas potensial perikanan laut

Table 1. Priority rank of criteria for determination of the potensial commodity of marine fisheries

\begin{tabular}{|c|c|c|c|}
\hline $\begin{array}{l}\text { Kriterial } \\
\text { Criteria }\end{array}$ & $\begin{array}{l}\text { Deskripsi/ } \\
\text { Description }\end{array}$ & $\begin{array}{l}\text { Bobot/ } \\
\text { Weight }\end{array}$ & $\begin{array}{l}\text { prioritas/ } \\
\text { Priority rank }\end{array}$ \\
\hline $\begin{array}{l}\text { Ketersediaan bahan } \\
\text { baku/ }\end{array}$ & $\begin{array}{l}\text { Volume produksi dan kontinuitas } \\
\text { pasokan bahan baku sepanjang musim }\end{array}$ & 0.431 & 1 \\
\hline Raw material availability & $\begin{array}{l}\text { Production volume and supply continuity } \\
\text { of raw material through the season }\end{array}$ & & \\
\hline Nilai ekonomis/ & $\begin{array}{l}\text { Harga jual bahan baku dan kemudahan } \\
\text { dalam pemasaran }\end{array}$ & 0.403 & 2 \\
\hline Economic value & Raw material price and easy to sell & & \\
\hline Diversifikasi/ & $\begin{array}{l}\text { Peluang bahan baku menjadi berbagai } \\
\text { ragam produk olahan }\end{array}$ & 0.108 & 3 \\
\hline Diversification & $\begin{array}{l}\text { Possibitily to process raw material into } \\
\text { various product }\end{array}$ & & \\
\hline Lokasi/ & $\begin{array}{l}\text { Penyebaran lokasi pendaratan bahan } \\
\text { baku }\end{array}$ & 0.057 & 4 \\
\hline Location & Distribution of fish landing places & & \\
\hline
\end{tabular}

Keterangan/Note

* Pembobotan kriteria dilakukan dengan mengambil pendapat pakar terkait dan dianalisis dengan teknik Proses Hierarki Analitik (PHA) melalui metode komparasi berpasangan

* Criteria weighting was carried out by using expert opinion and analysed using Analytical Hierarchy Process (AHP) with full pairwise method 
Tabel 2. Urutan prioritas alternatif komoditas potensial perikanan laut

Table 2. Priority rank of alternative potensial commodity of marine fisheries

\begin{tabular}{|c|c|c|c|c|c|c|c|}
\hline \multirow{2}{*}{\multicolumn{2}{|c|}{ Komoditas/Commodity }} & \multicolumn{4}{|c|}{ Kriteria/Criteria } & \multirow[b]{2}{*}{$\begin{array}{l}\text { Hasil/ } \\
\text { Result }\end{array}$} & \multirow[b]{2}{*}{$\begin{array}{c}\text { Urutan } \\
\text { Prioritas/ } \\
\text { Priority rank }\end{array}$} \\
\hline & & $\begin{array}{c}\text { Bahan } \\
\text { baku/ } \\
\text { Raw } \\
\text { material }\end{array}$ & $\begin{array}{c}\text { Nilai } \\
\text { ekonomis/ } \\
\text { Economic } \\
\text { value }\end{array}$ & $\begin{array}{c}\text { Diversifikasi/ } \\
\text { Diversification }\end{array}$ & $\begin{array}{l}\text { Lokasi/ } \\
\text { Location }\end{array}$ & & \\
\hline 1 & $\begin{array}{l}\text { Layang/ } \\
\text { Scads }\end{array}$ & 0.102 & 0.072 & 0.082 & 0.044 & 0.084 & 1 \\
\hline 2 & $\begin{array}{l}\text { Selar/ } \\
\text { Trevallies }\end{array}$ & 0.060 & 0.072 & 0.082 & 0.058 & 0.067 & 8 \\
\hline 3 & $\begin{array}{l}\text { Teri/ } \\
\text { Anchovies }\end{array}$ & 0.060 & 0.107 & 0.066 & 0.044 & 0.079 & 2 \\
\hline 4 & $\begin{array}{l}\text { Tembang/ } \\
\text { Fringescale sardinella }\end{array}$ & 0.078 & 0.053 & 0.082 & 0.058 & 0.067 & 7 \\
\hline 5 & $\begin{array}{l}\text { Kembung/ } \\
\text { Indian mackerel }\end{array}$ & 0.072 & 0.060 & 0.066 & 0.058 & 0.066 & 9 \\
\hline 6 & $\begin{array}{l}\text { Tengiri/ } \\
\text { Narrow barred king } \\
\text { mackerel }\end{array}$ & 0.054 & 0.089 & 0.099 & 0.102 & 0.076 & 3 \\
\hline 7 & $\begin{array}{l}\text { Tongkol/ } \\
\text { Eastern little tuna }\end{array}$ & 0.066 & 0.083 & 0.074 & 0.065 & 0.074 & 4 \\
\hline 8 & $\begin{array}{l}\text { Peperek/ } \\
\text { Pony fishes }\end{array}$ & 0.072 & 0.024 & 0.040 & 0.041 & 0.047 & 15 \\
\hline 9 & $\begin{array}{l}\text { Merah/ } \\
\text { Red snapper }\end{array}$ & 0.066 & 0.048 & 0.057 & 0.094 & 0.059 & 13 \\
\hline 10 & $\begin{array}{l}\text { Ekor Kuning/ } \\
\text { Yellow tail }\end{array}$ & 0.059 & 0.053 & 0.057 & 0.094 & 0.058 & 14 \\
\hline 11 & $\begin{array}{l}\text { Tigawaja/ } \\
\text { Drums }\end{array}$ & 0.059 & 0.060 & 0.066 & 0.065 & 0.060 & 11 \\
\hline 12 & $\begin{array}{l}\text { Paril } \\
\text { Rays }\end{array}$ & 0.066 & 0.060 & 0.057 & 0.065 & 0.062 & 10 \\
\hline 13 & $\begin{array}{l}\text { Rebon/ } \\
\text { Small shrimps }\end{array}$ & 0.071 & 0.041 & 0.066 & 0.087 & 0.059 & 12 \\
\hline 14 & $\begin{array}{l}\text { Cumi-cumi/ } \\
\text { Common squids }\end{array}$ & 0.060 & 0.083 & 0.074 & 0.073 & 0.072 & 5 \\
\hline & $\begin{array}{l}\text { Rajungan/ } \\
\text { Swim crab }\end{array}$ & 0.054 & 0.095 & 0.033 & 0.050 & 0.068 & 6 \\
\hline
\end{tabular}

Keterangan/Note: * Angka pada setiap alternatif komoditas merupakan pendapat pakar terkait yang diolah dengan teknik Proses Hierarki Analitik (PHA) melalui metode langsung

* Value at each alternative commodity was expert opinion analysed using Analytical Hierarchy Process (AHP) with direct method

Berdasarkan hasil pada Tabel 1 diketahui bahwa urutan kriteria dari yang terbesar adalah (1) ketersediaan bahan baku, (2) nilai ekonomis bahan baku, (3) peluang diversifikasi, kemudian (4) lokasi penyebaran bahan baku. Dengan demikian faktor ketersediaan dan kontinuitas bahan baku/komoditas merupakan faktor dominan di dalam menentukan prioritas komoditas potensial. Faktor ekonomis bahan baku merupakan faktor yang tidak dapat diabaikan dalam pengembangan agroindustri. Diharapkan dalam pengembangan agroindustri tidak hanya pengolah saja yang diuntungkan, tetapi juga harus menguntungkan pihak nelayan sebagai penghasil bahan baku. 
Komoditas perikanan yang memungkinkan adanya diversifikasi produk akan mempunyai nilai lebih jika dibandingkan dengan komoditas perikanan yang tidak mempunyai peluang diversifikasi produk. Hal ini penting untuk mengantisipasi adanya kejenuhan terhadap satu produk agroindustri baik dari segi permintaan maupun harga. Komoditas yang yang mempunyai kesempatan adanya diversifikasi produk lebih mudah beradaptasi dengan perubahan permintaan pasar

Faktor penyebaran lokasi komoditas harus diperhitungkan di dalam pengembangan suatu agroindustri. Komoditas yang diproduksi terpusat akan memudahkan dalam pengumpulan bahan baku sehingga akan menghemat biaya transportasi; sedangkan komoditas tersebar akan menyulitkan di dalam pengumpulannya sehingga akan meningkatkan biaya transportasi.

Berdasarkan hasil perhitungan setelah dilakukan pembobotan masing-masing kriteria dan skor alternatif dari 15 jenis komoditas, maka didapatkan urutan komoditas potensial untuk pengembangan produk unggulan agroindustri perikanan laut di Kabupaten Rembang seperti tercantum pada kolom terakhir Tabel 2. Selanjutnya 10 jenis ikan peringkat atas dianalisis kesesuaian teknologi pasca panennya

\section{Kesesuaian teknologi pasca panen}

Ikan dan produk perikanan merupakan bahan pangan yang sangat mudah rusak (highly perishable), sehingga diperlukan upaya penanganan yang tepat

Tabel 3. Nilai tingkat kesesuaian teknologi pasca panen bagi komoditas potensial perikanan laut Table 3. Fitting level scores of postharvest technology for potensial commodity of marine fisheries

\begin{tabular}{|c|c|c|c|c|c|c|c|c|c|c|c|}
\hline \multirow{2}{*}{\multicolumn{2}{|c|}{$\begin{array}{c}\text { Jenis Ikan } \\
\text { Kind of fish }\end{array}$}} & \multicolumn{10}{|c|}{ Teknologi Pasca Panen/Postharvest Technology } \\
\hline & & $a$ & b & C & d & $\mathrm{e}$ & $f$ & $\mathrm{~g}$ & $\mathrm{~h}$ & $i$ & j \\
\hline 1 & $\begin{array}{l}\text { Layang/ } \\
\text { Scads }\end{array}$ & 1 & 7 & 6.5 & 8 & 4.5 & 3 & 1 & 4.5 & 5 & 3 \\
\hline 2 & $\begin{array}{l}\text { Teril } \\
\text { Anchovies }\end{array}$ & 1 & 3 & 4 & 1 & 8 & 1 & 2 & 2 & 4 & 4 \\
\hline 3 & $\begin{array}{l}\text { Tengiril } \\
\text { Narrow barred king } \\
\text { mackerel }\end{array}$ & 1 & 7 & 7 & 1.5 & 3.5 & 4.5 & 1 & 7 & 5.5 & 1.5 \\
\hline 4 & $\begin{array}{l}\text { Tongkol/ } \\
\text { Eastern little tuna }\end{array}$ & 1 & 6.5 & 6.5 & 3.5 & 1 & 5.5 & 1 & 6.5 & 4 & 2.5 \\
\hline 5 & $\begin{array}{l}\text { Cumi-cumi/ } \\
\text { Common squids }\end{array}$ & 1 & 5 & 5 & 1 & 7.5 & 1 & 2 & 2 & 5 & 2 \\
\hline 6 & $\begin{array}{l}\text { Tembang/ } \\
\text { Fringescale sardinella }\end{array}$ & 1 & 3 & 2.5 & 2 & 6 & 5 & 1 & 5 & 3.5 & 5 \\
\hline 7 & $\begin{array}{l}\text { Rajungan/ } \\
\text { Swim crab }\end{array}$ & 1 & 3.5 & 1 & 1 & 1 & 1 & 1 & 8 & 4 & 3 \\
\hline 8 & $\begin{array}{l}\text { Selarl } \\
\text { Trevallies }\end{array}$ & 1 & 6.5 & 6.5 & 7 & 5 & 4.5 & 1 & 3.5 & 5 & 3 \\
\hline 9 & $\begin{array}{l}\text { Kembung/ } \\
\text { Indian mackerel }\end{array}$ & 1 & 7 & 5.5 & 7 & 3.5 & 4 & 1 & 4 & 4.5 & 2 \\
\hline 10 & $\begin{array}{l}\text { Pari/ } \\
\text { Rays }\end{array}$ & 1 & 4.5 & 2 & 1 & 5.5 & 6.5 & 1 & 1.5 & 2 & 1 \\
\hline
\end{tabular}

Keterangan (Note) :* (a) hidup; (b) segar; (c) pembekuan; (d) pemindangan; (e) pengasinan/pengeringan; ( $f$ ) pengasapan/pemanggangan; (g) fermentasi/terasi; (h) pengalengan; (i) surimi; (j) tepung ikan.

* (a) live; (b) fresh; (c) frozen; (d) boiled; (e) dried-salted; (f) smoking/broiling; (g) fermentation; (h) canning; (i) surimi; (j) fish meal

- Angka menunjukkan tingkat kesesuaian teknologi pasca panen yang berkisar antara 1 10 (sangat tidak sesuai - sangat sesuai)/scores indicated fitting level of postharvest technology in the range of 1 - 10 (very unfit - very fit) 
untuk mencegah proses pembusukan atau segera dilakukan pengolahan yang sekaligus merupakan upaya untuk pengawetan. Secara teknis, hasil perikanan laut dimanfaatkan dalam dua bentuk, yaitu bentuk segar dan olahan

Pemilihan teknologi pascapanen bagi sepuluh komoditas potensial terpilih dilakukan melalui skoring dengan menyajikan berbagai alternatif teknologi pascapanennya. Tingkat kesesuaian diberikan oleh para pakar dengan memberikan nilai 1 sampai 10 (sangat rendah-sangat tinggi sekali). Alternatif teknologi pasca panen yang akan digunakan sebagai dasar penanganan/pengolahan produk agroindustri yaitu hidup, segar, pembekuan, pemindangan, pengasinan/pengeringan, pengasapan/pemanggangan, fermentasi/terasi, surimi dan tepung ikan. Hasil pernilaian tingkat kesesuaian teknologi pascapanen tersebut disajikan pada Tabel 3.

Dari hasil penilaian kesesuaian teknologi pasca panen bagi komoditas potensial (Tabel 3) diketahui bahwa ikan layang, selar dan kembung lebih cocok apabila diproses dengan cara pemindangan; ikan teri, cumi-cumi dan tembang sesuai diproses dengan cara pengasinan/pengeringan; sedangkan ikan tengiri akan lebih cocok apabila diolah menjadi produk beku, ikan tongkol lebih cocok bila ditangani dalam bentuk segar, rajungan lebih berpotensi untuk dikalengkan, dan ikan pari akan sesuai apabila diperlakukan dengan pengasapan/pemanggangan. Dengan hasil tersebut maka produk agroindustri alternatif yang bisa dikembangkan adalah pindang ikan layang, pindang ikan selar, pindang ikan kembung, ikan teri kering asin, cumi-cumi kering asin, ikan tembang kering asin, ikan tengiri beku, ikan tongkol segar, rajungan kaleng dan ikan pari panggang.

\section{Pemilihan Produk Unggulan Agroindustri Perikanan Laut}

BAPPEDA Propinsi Jawa Tengah menggariskan bahwa kriteria pemilihan produk unggulan yang akan dikembangkan dilakukan berdasarkan kriteria sebagai berikut: (a) produk unggulan tersebut menggunakan sumber daya yang tersedia di kawasan tersebut, baik sumber daya alam, sumber daya manusia dan sumber daya fisik; (b) produk unggulan tersebut mempunyai nilai tambah yang tinggi sehingga akan memberikan keuntungan baik bagi investor mupun masyarakat sekitarnya; (c) produk unggulan tersebut mempunyai jaminan kelangsungan pemasaran, baik di pasaran domestik maupun ekspor; (d) produk unggulan tersebut mempunyai keterkaitan ke depan (forward linkage) dan ke belakang (backward linkage) terhadap produk-produk lain yang ada di wilayah kawasan dan wilayah sekitarnya; (e) produk unggulan tersebut memperhatikan kelestarian lingkungan hidup, dan; ( $f$ ) produk unggulan tersebut dikembangkan dengan memperhatikan upaya peningkatan pemberdayaan masyarakat setempat sebagai pemilik potensi dan sumber daya (Bappeda Prop. Jawa Tengah, 2000).

Berdasarkan pertimbangan tersebut disusun 9 (sembilan) kriteria untuk pemilihan produk unggulan agroindustri perikanan laut, yaitu (1) ketersediaan dan kontinuitas produksi bahan baku; (2) mutu bahan baku; (3) nilai tambah produk; (4) penguasaan teknologi yang digunakan; (5) Peluang pasar produk; (6) penyerapan tenaga kerja; (7) dampak ganda terhadap sektor lain; (8) dampak terhadap lingkungan; dan (9) kondisi pengembangan produk agroindustri saat ini. Setelah proses pembobotan dari sembilan kriteria tersebut, selanjutnya dilakukan proses pemilihan alternatif produk dengan memberikan skoring pada masing-masing produk alternatif

Hasil pembobotan dan skoring terhadap produk agroindustri unggulan yang potensial untuk dikembangkan di Kabupaten Rembang disajikan pada Tabel 4 dan Tabel 5. Dari berbagai kriteria, terlihat bahwa nilai tambah produk, ketersediaan dan kontinuitas bahan baku; serta peluang pasar merupakan faktor yang determinatif dalam menentukan produk unggulan agroindustri.

Nilai tambah sangat penting untuk diperhatikan bagi usaha agroindustri, karena menunjukkan besarnya keuntungan yang diperoleh apabila produk unggulan tersebut dikembangkan. Suatu usaha industri selalu bertujuan untuk mendapatkan keuntungan maksimal. Keyakinan untuk memperoleh keuntungan yang tinggi dari pelaksanaan suatu kegiatan usaha akan meningkatkan motivasi para in vestor untuk menanamkan modalnya dalam kegiatan agroindustri perikanan laut

Bahan baku merupakan faktor penentu yang akan sangat mempengaruhi kelangsungan agroindustri yang akan dikembangkan. Tanpa didukung oleh pasokan bahan baku secara kontinyu sulit bagi agroindustri dapat berlangsung dengan baik. Pengalaman menunjukkan banyak perusahaan agroindustri yang rontok di tengah jalan karena masalah kurangnya bahan baku dan kontinuitas tidak terjamin

Peluang pasar sangat penting karena akan menunjukkan prospek kebutuhan akan produk agroindustri yang akan diunggulkan baik untuk pasar dalam negeri maupun ekspor. Faktor ini merupakan faktor yang sangat mendukung upaya pengembangan, mengingat nelayan selalu kesulitan dalam memasarkan hasil tangkapan, sementara produk perikanan sangat rentan dengan penyimpanan yang cukup lama tanpa perlakuan. Potensi pasar menjadi kriteria determinatif yang penting karena akan 
menggambarkan prospek produk baik untuk memenuhi kebutuhan dalam negeri (lokal) maupun untuk pasar ekspor. Besarnya peluang pasar bagi produk unggulan agroindustri dapat menggambarkan besarnya potensi untuk pengembangan dan investasi

Dari kesepuluh alternatif produk unggulan agroindustri perikanan laut di Kabupaten Rembang, ikan teri asin dan pindang ikan layang terpilih sebagai produk unggulan dengan nilai total tertinggi yaitu
0,126 . Jenis produk lain yang potensial dikembangkan di Kabupaten Rembang berdasarkan urutan ketiga adalah pindang ikan selar.

\section{Analisis Kelayakan Usaha Produk Unggulan Agroindustri}

Untuk mengetahui tingkat kelayakan produk unggulan agroindustri perikanan laut di Kabupaten Rembang perlu dilakukan analisis finansial. Kriteria

Tabel 4. Urutan prioritas kriteria pemilihan produk unggulan agroindustri perikanan laut

Table 4. Priority rank of criteria for determination of the specialty products for marine fisheries agroindustry

\begin{tabular}{|c|c|c|c|}
\hline $\begin{array}{l}\text { Kriteria/ } \\
\text { Criteria }\end{array}$ & $\begin{array}{l}\text { Deskripsi/ } \\
\text { Description }\end{array}$ & $\begin{array}{l}\text { Bobot/ } \\
\text { Weight }\end{array}$ & $\begin{array}{c}\text { Urutan prioritasl } \\
\text { Priority rank }\end{array}$ \\
\hline $\begin{array}{l}\text { Bahan bakul } \\
\text { Raw material }\end{array}$ & $\begin{array}{l}\text { Volume produksi dan kontinuitas } \\
\text { pasokan bahan baku sepanjang musim } \\
\text { dan kondisi bahan baku/Production } \\
\text { volume and supply continuity of raw } \\
\text { material through the season and raw } \\
\text { material condition }\end{array}$ & 0.221 & 2 \\
\hline Mutu/Quality & $\begin{array}{l}\text { Kualitas bahan baku bagi kegiatan } \\
\text { agroindustri/Quality of raw material for } \\
\text { agroindustry activity }\end{array}$ & 0.114 & 4 \\
\hline $\begin{array}{l}\text { Nilai tambah/ } \\
\text { Value added }\end{array}$ & $\begin{array}{l}\text { Margin keuntungan kegiatan } \\
\text { pengolahan produk agroindustri/Profit } \\
\text { margin for processing activity of } \\
\text { agroindustry products }\end{array}$ & 0.227 & 1 \\
\hline $\begin{array}{l}\text { Teknologi/ } \\
\text { Technology }\end{array}$ & $\begin{array}{l}\text { Penguasaan teknologi yang digunakan } \\
\text { untuk menghasilkan produk } \\
\text { agroindustri/Adoption level of } \\
\text { techonolog used for the production of } \\
\text { agroindustry products }\end{array}$ & 0.082 & 5 \\
\hline Pasar/Market & $\begin{array}{l}\text { Peluang pasar produk yang dihasilkan } \\
\text { agroindustri/Market opportunity of } \\
\text { agroindustry products }\end{array}$ & 0.175 & 3 \\
\hline $\begin{array}{l}\text { Tenaga kerjal } \\
\text { Man power }\end{array}$ & $\begin{array}{l}\text { Penyerapan tenaga kerja oleh kegiatan } \\
\text { agroindustri/Man power intake by } \\
\text { agroindustry activity }\end{array}$ & 0.039 & 8 \\
\hline $\begin{array}{l}\text { Dampak } \\
\text { ganda/Double } \\
\text { impact }\end{array}$ & $\begin{array}{l}\text { Dampak kegiatan agroindustri terhadap } \\
\text { sektor lain/Impact of agroindustry } \\
\text { activity to other sectors }\end{array}$ & 0.041 & 7 \\
\hline $\begin{array}{l}\text { Lingkungan/ } \\
\text { Environment }\end{array}$ & $\begin{array}{l}\text { Dampak yang ditimbulkan oleh } \\
\text { kegiatan agroindustri terhadap } \\
\text { lingkungan//mpact of agroindustry } \\
\text { activity to environment }\end{array}$ & 0.061 & 6 \\
\hline $\begin{array}{l}\text { Kondisi } \\
\text { agroindustril } \\
\text { Agroindustry } \\
\text { condition }\end{array}$ & $\begin{array}{l}\text { Kondisi pengembangan produk } \\
\text { agroindustri saat sekarang/Present } \\
\text { condition of agroindustry development }\end{array}$ & 0.039 & 9 \\
\hline
\end{tabular}

Keterangan (Note) : * Pembobotan kriteria dilakukan dengan mengambil pendapat pakar terkait dan dianalisis dengan teknik Proses Hierarki Analitik (PHA) melalui metode komparasi berpasangan

* Criteria weighting was carried out by using expert opinion and analysed using Analytical Hierarchy Process (AHP) with full pairwise method 
Tabel 5. Urutan prioritas alternatif produk unggulan agroindustri perikanan laut

Table 5. Priority rank of alternative of the specialty products for marine fisheries agroindustry

\begin{tabular}{|c|c|c|c|c|c|c|c|c|c|c|c|}
\hline & $\begin{array}{l}\text { Jenis Produk/ } \\
\text { ind of products }\end{array}$ & $\begin{array}{c}\text { Bahan } \\
\text { bakul } \\
\text { Raw } \\
\text { material }\end{array}$ & $\begin{array}{l}\text { Mutul ta } \\
\text { Quali- } \\
\text { ty }\end{array}$ & $\begin{array}{l}\text { Nilai } \\
\text { tambah/ } \\
\text { Value } \\
\text { added }\end{array}$ & $\begin{array}{l}\text { Tekno- } \\
\text { logil } \\
\text { Techno- } \\
\text { logy }\end{array}$ & $\begin{array}{l}\text { Pasarl } \\
\text { Market }\end{array}$ & $\begin{array}{l}\text { Tenaga } \\
\text { kerjal } \\
\text { Man } \\
\text { power }\end{array}$ & $\begin{array}{c}\text { Dampak } \\
\text { ganda/ } \\
\text { Double } \\
\text { impact }\end{array}$ & $\begin{array}{l}\text { Ling- } \\
\text { kungan/ } \\
\text { Environ- } \\
\text { ment }\end{array}$ & $\begin{array}{c}\text { Kondisi } \\
\text { Agro- } \\
\text { industri/ } \\
\text { Agro- } \\
\text { industry } \\
\text { condition }\end{array}$ & $\begin{array}{l}\text { Hasil/ } \\
\text { Result }\end{array}$ \\
\hline 1 & $\begin{array}{l}\text { Pindang Layang/ } \\
\text { Boiled Scads }\end{array}$ & 0.141 & 0.114 & 0.122 & 0.110 & 0.132 & 0.134 & 0.130 & 0.090 & 0.154 & 0.126 \\
\hline 2 & $\begin{array}{l}\text { Teri Asin/ } \\
\text { Dried-salted } \\
\text { Anchovy }\end{array}$ & 0.113 & 0.114 & 0.134 & 0.155 & 0.132 & 0.156 & 0.130 & 0.098 & 0.103 & 0.126 \\
\hline 3 & $\begin{array}{l}\text { Tengiri Bekul } \\
\text { Frozen Narrow } \\
\text { barred king } \\
\text { mackerel }\end{array}$ & 0.076 & 0.098 & 0.067 & 0.066 & 0.082 & 0.067 & 0.087 & 0.116 & 0.077 & 0.079 \\
\hline 4 & $\begin{array}{l}\text { Tongkol Segar/ } \\
\text { Fresh Eastern } \\
\text { little tuna }\end{array}$ & 0.095 & 0.089 & 0.067 & 0.054 & 0.082 & 0.055 & 0.071 & 0.116 & 0.063 & 0.080 \\
\hline 5 & $\begin{array}{l}\text { Cumi-cumi asin/ } \\
\text { Dried-salted } \\
\text { Common squids }\end{array}$ & 0.076 & 0.089 & 0.100 & 0.086 & 0.082 & 0.077 & 0.071 & 0.098 & 0.087 & 0.086 \\
\hline 6 & $\begin{array}{l}\text { Tembang Asin/ } \\
\text { Dried-salted } \\
\text { Fringescale } \\
\text { sardinella }\end{array}$ & 0.104 & 0.081 & 0.089 & 0.099 & 0.082 & 0.110 & 0.087 & 0.090 & 0.077 & 0.091 \\
\hline 7 & $\begin{array}{l}\text { Rajungan } \\
\text { Canned Swim } \\
\text { crab }\end{array}$ & 0.065 & 0.114 & 0.144 & 0.177 & 0.112 & 0.145 & 0.117 & 0.098 & 0.077 & 0.114 \\
\hline 8 & $\begin{array}{l}\text { Pindang Selar/ } \\
\text { Boiled Trevallies }\end{array}$ & 0.132 & 0.114 & 0.122 & 0.110 & 0.132 & 0.134 & 0.130 & 0.090 & 0.154 & 0.124 \\
\hline 9 & $\begin{array}{l}\text { Pindang } \\
\text { kembung/ } \\
\text { Boiled Indian } \\
\text { mackerel }\end{array}$ & 0.104 & 0.098 & 0.067 & 0.066 & 0.082 & 0.067 & 0.087 & 0.106 & 0.089 & 0.085 \\
\hline 10 & $\begin{array}{l}\text { Pari Panggang/ } \\
\text { Smoked rays }\end{array}$ & 0.095 & 0.089 & 0.089 & 0.076 & 0.082 & 0.055 & 0.087 & 0.098 & 0.118 & 0.088 \\
\hline \multicolumn{2}{|c|}{ Keterangan/Note: } & $\begin{array}{l}\text { Value } \\
\text { Proce }\end{array}$ & thomp & $m$ & 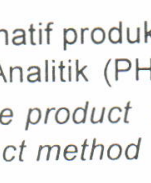 & 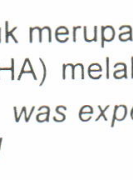 & $\tan p$ & 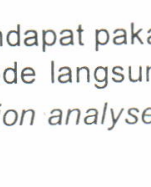 & 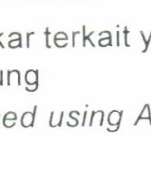 & anc & $n g$ \\
\hline
\end{tabular}

yang digunakan adalah Net Present Value (NPV), Internal Rate of Return (IRR), dan Net Benefit Cost Ratio (Net B/C). Penentuan layak atau tidaknya suatu usaha adalah dengan cara membandingkan masingmasing nilai kriteria kelayakan dengan batas-batas kelayakannya. Selain itu juga dilakukan penghitungan Pay Back Period (PBP) untuk mengetahui jumlah periode (tahun) yang diperlukan untuk mengembalikan (menutup) ongkos investasi awal dengan tingkat pengembalian tertentu.

Mengingat berbagai keterbatasan maka diperlukan asumsi-asumsi untuk mempermudah perhitungan, seperti yang disajikan pada Tabel 6. Asumsi didasarkan pada data yang diperoleh melalui kuesioner seperti kebutuhan bahan baku, jumlah produksi, harga bahan baku, harga produk dan target pasar serta 
Tabel 6. Asumsi yang digunakan untuk analisis kelayakan usaha produk unggulan agroindustri perikanan laut

Table 6. Asumption used for feasibility analysis of the specialty products for marine fisheries agroindustry

\begin{tabular}{|c|c|c|c|}
\hline No. & $\begin{array}{l}\text { Asumsi/ } \\
\text { Asumption }\end{array}$ & $\begin{array}{l}\text { Ikan Teri Asin/ } \\
\text { Dried-salted } \\
\text { Anchovy }\end{array}$ & $\begin{array}{l}\text { Layang/ } \\
\text { Boiled Scads }\end{array}$ \\
\hline \multirow[t]{2}{*}{1.} & Umur proyek/ & 5 tahun & 5 tahun \\
\hline & Project life & 5 years & 5 years \\
\hline 2. & $\begin{array}{l}\text { Kebutuhan bahan baku } \\
\text { (volume bahan baku/tahun)/ } \\
\text { Raw material requirement } \\
\text { (raw material volume/year) }\end{array}$ & 300 ton & 600 ton \\
\hline 3. & $\begin{array}{l}\text { Jumlah produksi } \\
\text { (produk/tahun)/ } \\
\text { Production quantity } \\
\text { (product/year) }\end{array}$ & 60 ton & 450 ton \\
\hline 4. & $\begin{array}{l}\text { Jumlah hari kerja/ } \\
\text { Working days }\end{array}$ & $\begin{array}{c}25 \text { hari/bulan } \\
25 \text { days/month }\end{array}$ & $\begin{array}{l}25 \text { hari/bulan } \\
25 \text { days/month }\end{array}$ \\
\hline 5 & $\begin{array}{l}\text { Harga bahan baku per kg/ } \\
\text { Raw material price per kg }\end{array}$ & Rp. 8.000,- & Rp. 5.000,- \\
\hline \multirow[t]{4}{*}{6.} & Harga jual produk per kg/ & & \\
\hline & Product price per kg & & \\
\hline & $\begin{array}{l}\text { Lokal/antar kota } \\
\text { Local/intercity }\end{array}$ & Rp. $25.000,-$ & Rp. $12.500,-$ \\
\hline & $\begin{array}{l}\text { Eksporl } \\
\text { Export }\end{array}$ & Rp. $100.000,-$ & - \\
\hline 7. & $\begin{array}{l}\text { Bunga bank/ } \\
\text { Interest rate }\end{array}$ & $\begin{array}{l}19 \% / \text { tahun } \\
19 \% / \text { year }\end{array}$ & $\begin{array}{l}19 \% / \text { tahun } \\
19 \% / \text { year }\end{array}$ \\
\hline \multirow[t]{2}{*}{8.} & $\begin{array}{l}\text { Persentase biaya } \\
\text { penyusutan/ }\end{array}$ & $20 \% /$ tahun & $20 \% /$ tahun \\
\hline & Percentage of depreciation & $20 \% /$ year & $20 \% /$ year \\
\hline \multirow[t]{2}{*}{9.} & $\begin{array}{l}\text { Persentase biaya pajak } \\
\text { bangunan/ }\end{array}$ & $2 \% /$ tahun & $2 \% /$ tahun \\
\hline & Percentage of building tax & $2 \% /$ year & $2 \% /$ year \\
\hline \multirow[t]{4}{*}{10.} & Persentase produk terjual/ & $75 \%$ & \\
\hline & Percentage of sold product & & $75 \%$ \\
\hline & - Tahun I/Year I & $80 \%$ & $80 \%$ \\
\hline & $\begin{array}{l}\text { - Tahun II/Year II } \\
\text { - Tahun III-V/Year III-V }\end{array}$ & $85 \%$ & $85 \%$ \\
\hline \multirow[t]{4}{*}{11.} & Target pasar/Market target & & \\
\hline & Lokal/antar kota & & \\
\hline & $\begin{array}{l}\text { Local/intercity } \\
\text { Ekspor/ }\end{array}$ & $50 \%$ & $100 \%$ \\
\hline & Export & $50 \%$ & - \\
\hline
\end{tabular}

kondisi umum yang berlaku seperti besar bunga bank, penyusutan dan pajak bangunan. Berbagai kebutuhan permodalan untuk kegiatan usaha agroindustri, baik modal investasi, modal tetap, maupun modal kerja (variabel) disajikan pada Tabel 7
Dalam pengembangan industri pengeringan-asin ikan teri dan pemindangan ikan layang di Kabupaten Rembang, biaya investasi awal yang dikeluarkan untuk merealisasikan usaha tersebut masing-masing adalah sebesar Rp. 115.600.000,- dan Rp. 47.175.000,-yang 
Tabel 7. Modal usaha produk unggulan agroindustri perikanan laut

Table 7. Capital cost of investment of the specialty products for marine fisheries agroindustry

\begin{tabular}{|c|c|c|c|c|c|}
\hline \multirow{2}{*}{\multicolumn{2}{|c|}{$\begin{array}{c}\text { Kategori biaya/Cost } \\
\text { category }\end{array}$}} & \multicolumn{2}{|c|}{$\begin{array}{c}\text { Ikan Teri Asin/ } \\
\text { Dried-salted Anchovy }\end{array}$} & \multicolumn{2}{|c|}{$\begin{array}{c}\text { Pindang Ikan Layang/ } \\
\text { Boiled Scads }\end{array}$} \\
\hline & & $\begin{array}{c}\text { Uraian/ } \\
\text { Description }\end{array}$ & $\begin{array}{l}\text { Total biaya }(R p) / \\
\text { Total cost }(R p)\end{array}$ & $\begin{array}{c}\text { Uraian/ } \\
\text { Description }\end{array}$ & $\begin{array}{c}\text { Total biaya }(R p) / \\
\text { Total cost }(R p)\end{array}$ \\
\hline $\bar{A}$. & $\begin{array}{l}\text { Biaya investasi/ } \\
\text { Investment cost }\end{array}$ & & & & \\
\hline 1. & Tanah/Land & $1500 \mathrm{~m}^{2} \times \operatorname{Rp} 50.000$ & 75.000 .000 & $350 \mathrm{~m}^{2} \times \operatorname{Rp} 50.000$ & 17.500 .000 \\
\hline 2. & Bangunan/Building & $160 \mathrm{~m}^{2} \times \operatorname{Rp} 100.000$ & 16.000 .000 & $250 \mathrm{~m}^{2} \times \mathrm{Rp} 100.000$ & 25.000 .000 \\
\hline \multirow[t]{2}{*}{3.} & $\begin{array}{l}\text { Peralatan } \\
\text { Pengolahan/ } \\
\text { Processing } \\
\text { equipment }\end{array}$ & - & 24.600 .000 & - & 4.675 .000 \\
\hline & Jumlah A/Total A & & 115.600 .000 & & 47.175 .000 \\
\hline B. & $\begin{array}{l}\text { Biaya Tetap/ } \\
\text { Fixed cost }\end{array}$ & & & & \\
\hline 1. & $\begin{array}{l}\text { Bunga kredit/ } \\
\text { Interest rate }\end{array}$ & $19 \%$ & 21.964 .000 & $19 \%$ & 8.963 .250 \\
\hline 2. & $\begin{array}{l}\text { Penyusutan/ } \\
\text { Depreciation }\end{array}$ & $20 \%$ & 23.120 .000 & $20 \%$ & 9.435 .000 \\
\hline \multirow[t]{2}{*}{3.} & $\begin{array}{l}\text { Pajak bangunan/ } \\
\text { Building tax }\end{array}$ & $2 \%$ & 1.820 .000 & $2 \%$ & 850.000 \\
\hline & Jumlah B/Total B & & 46.904 .000 & & 19.248 .250 \\
\hline C & $\begin{array}{l}\text { Biaya Variabel/ } \\
\text { Variable cost }\end{array}$ & & & & \\
\hline 1. & $\begin{array}{l}\text { Gaji karyawan/ } \\
\text { Salary }\end{array}$ & $\begin{array}{l}\text { Tetap \& borongan/ } \\
\text { Fixed \& contract }\end{array}$ & 207.000 .000 & $\begin{array}{l}\text { Tetap \& borongan/ } \\
\text { Fixed \& contract }\end{array}$ & 264.000 .000 \\
\hline 2. & $\begin{array}{l}\text { Bahan baku/Raw } \\
\text { material }\end{array}$ & $\begin{array}{c}12 \text { bulan (month) } \times 25 \\
\text { hari }(\text { days }) \times 1 \text { ton } \times \mathrm{Rp} \\
8.000,-\end{array}$ & 2.400 .000 .000 & $\begin{array}{c}12 \text { bulan (month) } \times 25 \\
\text { hari (days) } \times 2 \text { ton } \times R p \\
5.000\end{array}$ & 3.000 .000 .000 \\
\hline 3. & $\begin{array}{l}\text { Bahan penunjang/ } \\
\text { Supporting material }\end{array}$ & $\begin{array}{l}\text { garam, plastik/ } \\
\text { salt, plastic }\end{array}$ & 3.500 .000 & $\begin{array}{l}\text { garam, reyeng/ } \\
\text { salt, reyeng }\end{array}$ & 231.894 .231 \\
\hline 4. & Utilitas/Utility & $\begin{array}{l}\text { listrik, gas, m. tanah/ } \\
\text { electric, gas, cerosene }\end{array}$ & 13.080 .000 & $\begin{array}{l}\text { listrik, minyak tanah/ } \\
\text { electric, cerosene }\end{array}$ & 32.820 .000 \\
\hline 5. & $\begin{array}{l}\text { Pemasaran/ } \\
\text { Marketing }\end{array}$ & $\begin{array}{c}12 \text { bulan (month) } \times R p . \\
1.500 .000,-\end{array}$ & 18.000 .000 & $\begin{array}{c}12 \text { bulan (month) } \times 25 \\
\text { hari (days) } \times 2 \text { ton } \times R p \\
250,-\end{array}$ & 750.000 .000 \\
\hline & Jumlah C/Total C & & 2.641 .580 .000 & & 4.278 .714 .231 \\
\hline & $\begin{array}{l}\text { mlah B+C } \\
\text { tal B +C }\end{array}$ & & 2.688 .484 .000 & & 4.297 .962 .481 \\
\hline
\end{tabular}

terdiri dari biaya untuk tanah, bangunan, serta mesin dan peralatan pengolahan (Tabel 7). Biaya tetap per tahun dihitung berdasarkan kebutuhan untuk membayar bunga kredit dan angsuran atau penyusutan (dalam hal ini penyusutan dihitung flat selama 5 tahun untuk semua jenis barang investasi). Biaya variabel per tahun dalam perhitungan ini diantaranya meliputi gaji karyawan, harga ikan segar, harga bahan penunjang seperti garam dan pengemas, serta utilitas seperti listrik, gas dan minyak tanah. 
Dengan perencanaan kapasitas produksi sebesar 1 ton ikan teri dan 2 ton ikan layang segar per hari, industri pengeringan-ikan teri asin dan pemindangan ikan layang di Kabupaten Rembang dinyatakan layak untuk diusahakan berdasarkan kriteria-kriteria kelayakan (Tabel 8). Menurut Kadariah et al., 1978, usaha layak untuk diteruskan apabila nilai $\mathrm{B} / \mathrm{C}>1$, NPV positif dan IRR lebih besar dari bunga bank yang berlaku saat perhitungan.

Untuk 300 hari kerja dalam setahun, kebutuhan ikan teri dan ikan layang segar yang harus tersedia agar target produksi terpenuhi adalah 300 ton dan 600 ton per tahun. Jumlah tersebut setara dengan 1,6\% dari total produksi ikan teri dan 0,005\% dari total produksi ikan layang di Kabupaten Rembang tahun 1999. Hal ini menunjukkan ketersediaan bahan baku sangat memadai untuk mensuplai kebutuhan industri selama 5 tahun proyek.

Penurunan jumlah produksi dan peningkatan harga bahan baku sangat mungkin terjadi diantaranya apabila potensi bahan baku menyusut, musim yang tidak baik atau peningkatan harga bahan bakar yang menyebabkan biaya produksi menjadi meningkat. Beberapa skenario dan hasil analisis kelayakan disajikan pada Tabel 8. Analisis sensitivitas untuk beberapa skenario finansial menjadi sangat penting diketahui untuk menghindarkan usaha dari kerugian.

Dari Tabel 8 dapat disimpulkan bahwa penurunan jumlah produksi bahan baku sampai $50 \%$ usaha masih layak untuk dikembangkan. Akan tetapi apabila penurunan jumlah bahan baku diikuti pula dengan peningkatan harga ikan sampai $11 \%$ untuk ikan teri segar dan $8 \%$ untuk ikan layang segar, usaha tersebut sudah tidak layak lagi. Hal ini kemungkinan bias terjadi pada musim paceklik, dimana jumlah produksi menurun dan harga ikan meningkat. Untuk mengatasi peningkatan biaya produksi yang diakibatkan oleh peningkatan harga ikan dapat diatasi dengan meningkatkan harga jual produk, yaitu $2 \%$ untuk ikan teri kering-asin dan 3\% untuk pindang ikan layang

\section{KESIMPULAN}

Ketersediaan bahan baku dan nilai ekonomis bahan baku merupakan faktor yang determinatif dalam

Tabel 8. Nilai kelayakan usaha dengan berbagai skenario perubahan jumlah bahan baku, harga bahan baku dan harga produk jadi

Table 8. Feasibility value at various scenario of changes in raw material volume, raw material price and product price

\begin{tabular}{ccccc}
\hline \multirow{2}{*}{$\begin{array}{c}\text { Skenariol } \\
\text { Scenario }\end{array}$} & \multicolumn{5}{c}{ Krite ria Kelayakan Usaha/Feasibility Criteria } \\
\cline { 2 - 5 } & B/C & NPV (Rp) & IRR (\%) & PBP (Tahun/year) \\
\hline Ikan Teri Kering Asin/Dried-salted Anchovy & & \\
0 & 1,14 & 968.241 .674 & 183,78 & 0,52 \\
1 & 1,12 & 347.488 .894 & 89,54 & 0,79 \\
2 & 1,02 & -56.118 .911 & 8,04 & 2,01 \\
3 & 1,04 & 36.867 .881 & 26,11 & 1,73 \\
Pindang Ikan Layang/Boiled Scads & & \\
0 & 1,07 & 761.842 .839 & 152,91 & 1,31 \\
1 & 1,04 & 152.559 .142 & 52,95 & 1,78 \\
2 & 1,01 & -67.292 .450 & 5,59 & 2,3 \\
3 & 1,04 & 141.629 .714 & 49,55 & 1,82 \\
\hline
\end{tabular}

Keterangan/Note

Skenario 0 : Kondisi normal produksi/Scenario 0: Normal condition of production

Skenario 1 : Jumlah bahan baku turun 50\%/Scenario 1: Raw material volume decrease 50\%

Skenario 2 : Jumlah bahan baku turun $50 \%$ dan harga bahan baku naik $11 \%$ untuk ikan teri dan $8 \%$ untuk ikan layang/Scenario 2: Raw material volume decrease $50 \%$ and raw material price increase $11 \%$ for Anchovy and $8 \%$ for Scads

Skenario 3 : Jumlah bahan baku turun $50 \%$, harga bahan baku naik $11 \%$ dan harga produk naik $2 \%$ untuk teri kering, serta harga bahan baku naik $8 \%$ dan harga produk naik 3\% untuk pindang layang/Scenario 3: Raw material volume decrease $50 \%$, raw material and product price increase $11 \%$ and $2 \%$ respectively for Dried-salted Anchovy; and raw material and product price increase $8 \%$ and 3 for Scads 
penilaian alternatif komoditas potensial. Dalam penentuan produk unggulan agroindustri, terlihat bahwa nilai tambah produk, ketersediaan dan kontinuitas bahan baku; serta peluang pasar merupakan faktor yang determinatif. Dari hasil pembobotan dan skoring terhadap beberapa jenis komoditas dan teknologi pasca panen yang digunakan diketahui bahwa produk agroindustri perikanan laut yang dapat diunggulkan di Kabupaten Rembang adalah ikan teri kering-asin dan pindang ikan layang.

Usaha ikan teri kering-asin dan pindang ikan layang di Kabupaten Rembang layak dikembangkan. Hasil analisis sensitivitas memberikan petunjuk bahwa apabila jumlah bahan baku turun sebesar $50 \%$ usaha kedua produk masih layak untuk dikembangkan. Apabila penurunan jumlah bahan baku $50 \%$ tersebut diikuti dengan kenaikan harga, maka kenaikan harga yang bisa ditoleransi adalah kurang dari $11 \%$ untuk ikan teri dan $8 \%$ untuk ikan layang, lebih besar atau sama dengan nilai tersebut usaha menjadi tidak layak lagi untuk dikembangkan. Upaya yang harus dilakukan bila terjadi penurunan bahan baku dan kenaikan harga sampai batas diatas dapat diatasi dengan cara meningkatkan harga jual produk, yaitu minimal $2 \%$ untuk ikan teri kering-asin dan 3\% untuk pindang ikan layang.

Hasil penelitian diatas dapat dijadikan masukan bagi Pemerintah Daerah Kabupaten Rembang dalam pengembangan potensi perikanan laut yang dimiliki khususnya didasarkan pada tingkat penguasaan teknologi pasca panen dan peluang pasar bagi produk yang dikembangkan. Pemanfaatan teknologi pasca panen yang tepat juga dapat dimaksudkan untuk mendapatkan nilai tambah produk secara optimal bagi potensi yang dimiliki sebesar-besarnya baik dalam hitungan finansial maupun manfaat lain sepert terserapnya tenaga kerja setempat dan dampak ganda yang ditimbulkan terhadap sektor lain.

\section{DAFTAR PUSTAKA}

Austin, J.E. 1992. Agroindustrial Project Analysis. EDI Series in Economic Development. Washington D.C

BAPPEDA, Prop Jateng. 2000. Penyusunan Rencana Pengelolaan Kawasan Rawa Pening Prop Jateng 2000. Pusat Penelitian Perencanaan Pembangunan Nasional - Universitas Gajah Mada. Yogyakarta

BPS Prop. Jateng. 1997. Jawa Tengah dalam Angka 1997. BPS dan BAPPEDA Propinsi Jawa Tengah

BPS Prop. Jateng. 2002. Jawa Tengah dalam Angka 2002. BPS dan BAPPEDA Propinsi Jawa Tengah

Brown, J.G. 1994. Agroindustrial Investment and Operations. Economic Development Institute of The World Bank. The World Bank, Washington, D.C.

Irianto, H.E., Murniyati, Poernomo, A. dan Astuti, I.R. 2001. Ketersediaan bahan baku untuk industri perikanan dan potensi limbah yang dihasilkan : Studi Kasus Di DKI Jakarta. Analisis Kebijaksanaan Pembangunan Perikanan 2000. Pusris Perikanan Budidaya, Dep. Kelautan dan Perikanan, Jakarta.

Kadariah, Karlina, L. dan Gray, C. 1978. Pengantar Evaluasi Proyek. Fakultas Ekonomi, UI, Jakarta

Nasution, M. 2002. Pengembangan Kelembagaan Koperasi Pedesaan Untuk Agroindustri. IPB Press, Bogor.

Poernomo, A., Heruwati, E.S., Irianto, H.E., Pranadji, T. , Murniyati, dan Astuti, I.R. 2001. Pemberdayaan Industri Pengolahan Ikan di Indonesia: Sebuah Perspektif. Analisis Kebijaksanaan Pembangunan Perikanan 2000. Pusris Perikanan Budidaya, Dep Kelautan dan Perikanan, Jakarta.

Saaty, T.L. 1980. The Analytical Hierarchy Process McGraw-Hill Inc., USA. 
